\title{
Marek REWIZORSKI
}

Koszalin

\section{Sytuacja kobiet na europejskim rynku pracy}

\section{Wprowadzenie}

$\mathbf{Z}$ miany wywoływane przez globalizację, niestabilność demograficzną, postęp technologiczny, niskie tempo wzrostu gospodarczego i pogarszającą się sytuację sektora finansów publicznych stawiają pod znakiem zapytania realizację jednego z najważniejszych celów Unii Europejskiej, do których należy osiagnięcie pełnego zatrudnienia. $\mathrm{Z}$ pewnością nie udało się go zrealizować w pierwszych latach XXI wieku, czego dowodem jest fakt, że zadania dotyczące rynku pracy nakreślone przez Radę Europejską w marcu 2000 roku w Lizbonie nie zostały wykonane ${ }^{1}$. Problemem stał się globalny kryzys finansowy, który dotarł do Europy w 2007 roku. Pomimo stopniowego ożywienia światowej gospodarki bezrobocie na jej obszarze w dalszym ciągu wzrasta i w niektórych krajach Unii Europejskiej przekroczyło już wskaźnik dziesięcioprocentowy. Coraz bardziej nabrzmiały staje się problem ubóstwa, którym jest zagrożone prawie 80 milionów Europejczyków. Codziennie zmagają się oni z niepewnością i brakuje im środków do zaspokojenia najbardziej podstawowych potrzeb: żywności, odzieży, dachu nad głową. Ubóstwo dotykające coraz większą liczbę osób ogranicza również możliwość dokonania swobodnego wyboru stylu życia, co może prowadzić do wykluczenia społecznego. Nie dziwi zatem fakt, że Unia Europejska ogłosiła 2010 rok - Europejskim Rokiem Walki z Ubóstwem i Wykluczeniem Społecznym². W obliczu problemów gospodarczych, występujących zwłaszcza w krajach PIGS (Portugalia, Irlandia, Grecja, Hiszpania), zmagających się z ogromnym długiem publicznym, w UE coraz częściej stosuje się narzędzia mające przywrócić stabilizację w gospodarkach narodowych poszczególnych krajów, jak i na krajowych rynkach pracy. Bezrobocie, które pod koniec 2010 r. osiagnęło $\mathrm{w}$ niektórych państwach UE poziom blisko $20 \%$, staje się widmem, z którym większość krajów nie jest w stanie poradzić sobie w pojedynkę.

Bardzo interesująca w aspekcie współczesnych przemian na europejskim rynku pracy jest pozycja, jaką zajmują na nim kobiety. Tradycyjnie bowiem jest to grupa, której sytuacja na rynkach pracy poszczególnych państw Unii Europejskiej jest bardzo zróżnicowana i charakteryzuje się znaczną dynamiką. $Z$ jednej strony potencjał zawodowy kobiet wciąż wzrasta, z drugiej zaś stopień jego wykorzystania na europejskim rynku pracy pozostawia wiele do życzenia. Pomimo istnienia szeregu norm prawnych w dziedzinie równouprawnienia i uznania niniejszej problematyki za priorytet w strategiach: „Lizbońskiej” oraz „Europa 2020”, wciąż widoczny jest brak równowagi pomiędzy liczbą kobiet i mężczyzn zatrudnianych w różnych

\footnotetext{
${ }^{1}$ Zaliczono do nich dążenie do osiągnięcia stopy zatrudnienia w UE na poziomie $70 \%$ (wśród kobiet - $60 \%$, a osób w wieku 55-64 lata-50\%).

${ }^{2}$ Europa łaczy siły $w$ walce z ubóstwem i wykluczeniem społecznym, komunikat prasowy Parlamentu Europejskiego nr 20100212STO68925, www.europarl/europa.eu z 15.02.2010 r.
} 
dziedzinach gospodarki i zawodach. Przykładowo kobiety zarabiają zwykle mniej niż mężczyźni zatrudnieni na tych samych stanowiskach (zjawisko tzw. gender pay gap). Pomimo postępu przejawiającego się w ostatnich latach zwiększeniem zatrudnienia kobiet na stanowiskach menadżerskich, wciąż widoczna jest przewaga mężczyzn na tych posadach. Taki stan rzeczy thumaczy się zazwyczaj niższym poziomem wykształcenia kobiet i tradycyjnej ich koncentracji w pewnych typach zawodów (np. prace biurowe czy urzędnicze), które generalnie są w Unii słabiej płatne niż prace fizyczne, gdzie dominują mężczyźni. Na zmniejszenie szans kobiet na rynku pracy wpływają też stereotypy ról płciowych, które można charakteryzować jako zbiór przekonań o tym, jakie rodzaje aktywności są odpowiednie dla kobiet i mężczyzn. Jak wskazuje I. Andruszkiewicz, aktualnie funkcjonują dwa równoległe stereotypy: tradycyjny i nowoczesny. Drugi z nich zawiera w sobie niektóre cechy stereotypowo męskie i niekoniecznie musi zawierać wszystkie cechy typowo kobiece ${ }^{3}$. Co ciekawe, stereotypizacja bezrobotnego mężczyzny wyraża się zazwyczaj w przypisywaniu mu jednoznacznie pozytywnych właściwości, takich jak aktywność czy inicjatywa. Z kolei bezrobotne kobiety utożsamia się głównie z pełnieniem przez nie funkcji matki i żony (np. stereotyp matki Polki), w związku z czym zakłada się, że praca zawodowa nie jest dla nich istotna. Takie - niewatpliwie krzywdzące - dla kobiet ujęcie jest jednocześnie szkodliwym społecznie uogólnieniem. Nie uwzględnia się bowiem faktu, że w ustawodawstwach państw europejskich praca w gospodarstwie domowym jest równoważna z pracą poza domem. Warto tu też podkreślić różnorodność przyczyn nieaktywności zawodowej kobiet. Niejednolita jest ich sytuacja rodzinna, finansowa, wiekowa oraz wykształcenie. Pomimo to kobiety coraz częściej chcą uczestniczyć w życiu zawodowym i gospodarczym. Niniejszy artykuł służy zidentyfikowaniu różnic w sytuacji kobiet i mężczyzn na rynkach pracy w krajach Unii Europejskiej. Analizie zostaną poddane aspekty prawne, polityczne i społeczne aktywności zawodowej kobiet z zastosowaniem tzw. Benchmarkingu, czyli sformalizowanego procesu wzajemnego porównywania zjawisk zatrudnieniowych w różnych krajach w celu wyłonienia najlepszego kraju, ustanowienia globalnych celów postępu w dziedzinie zatrudnienia w długim i średnim okresie i zidentyfikowania najefektywniejszych polityk podnoszących poziom działań ${ }^{4}$.

\section{Normatywne podstawy zakazu dyskryminacji na rynku pracy w UE}

Dla uregulowania sytuacji kobiet na rynku pracy w UE szczególne znaczenie mają zapisy przeciwdziałające wszelkim przejawom dyskryminacji w zakresie zatrudnienia. Zwalczanie tego zjawiska leży u podstaw porządku prawnego Unii opartego na wspólnych zasadach poszanowania godności osoby ludzkiej, wolności, demokracji, równości, państwa prawnego oraz poszanowania praw człowieka, w tym praw osób należących do mniejszości. Dla wszystkich społeczeństw Europy wspólne jest fundamentalne przekonanie, że wszyscy ludzie są równi i że wszyscy powinni mieć sprawiedliwy dostęp do szans oferowanych przez życie. Dyskryminacja jest zjawiskiem, które podważa te wspólne wartości. Przeświadczenie to ma swoje miejsce w art. 3 TUE i art. 8 TFUE, które wprowadzają wspieranie równości mężczyzn i kobiet jako jeden z podstawowych celów Unii Europejskiej.

\footnotetext{
${ }^{3}$ I. Andruszkiewicz, Konsekwencje zjawiska bezrobocia wśród kobiet, „Przegląd Politologiczny” 2009, nr 1, s. 97.

${ }^{4}$ European Commission, Joint Employment Report 1997, DG V, Brussels 1997.
} 
W dużej ogólności dyskryminacja to każde działanie odmawiające określonym osobom lub grupom osób równego traktowania $\mathrm{w}$ porównaniu $\mathrm{z}$ innymi z powodu przynależności do określonej grupy społecznej, religijnej, narodowej itp. ${ }^{5}$ Do czasu wejścia w życie Traktatu z Lizbony powyższe zagadnienie uregulowano w art. 12 i 13 Traktatu o Wspólnocie Europejskiej (TWE), traktatowych postanowieniach szczególnych (zwłaszcza art. 34 ust. 2, 39, 43, $49,141)$, dyrektywach wydanych na podstawie art. 13 TWE oraz bogatym orzecznictwie ETS. Zgodnie z art. 12 TWE, w zakresie obowiązywania traktatu zakazana została wszelka dyskryminacja ze względu na przynależność państwową, a zatem traktowanie podmiotu z innego państwa członkowskiego (osoby fizycznej lub podmiotu gospodarczego) gorzej niż własnych podmiotów ${ }^{6}$. Po wejściu w życie Traktatu z Lizbony dawny art. 12 TWE został zastappiony przez art. 18 Traktatu o funkcjonowaniu Unii Europejskiej (TFUE), w którym zachowano wyżej wskazane brzmienie zasady zakazu dyskryminacji ze względu na przynależność państwową. Zakaz dyskryminacji na rynku pracy w UE, wynikający z ogólnego art. 18 TFUE, wzmocniono ponadto szeregiem postanowień zawartych w przepisach szczególnych.

Podstawowym postanowieniem prawa pierwotnego UE w zakresie zapewnienia równości płci jest art. 157 TFUE (d. 141 TWE) mający charakter przepisu szczególnego wobec art. 18 TFUE. Co istotne, nadano mu bezpośrednią skuteczność w związku z faktem, że zawiera on jasny i bezwarunkowy obowiązek, który nadaje się do tworzenia praw dla jednostki. Stanowisko takie zostało zaprezentowane w głośnym orzeczeniu ETS z 8 kwietnia 1978 r. w sprawie 43/75 Defrenne II, w którym pani Gabrielle Defrenne, stewardesa szwajcarskich linii lotniczych Sabena wniosła powództwo o odszkodowanie z tytułu utraconych zarobków i innych strat w związku koniecznością przejścia w stan spoczynku w wieku 40 lat. Powołała się przy tym na argument, że mężczyźni na tym samym stanowisku mogli pracować dłużej, a w konsekwencji uzyskiwali wyższe zarobki oraz uprawnienie do wyższych świadczeń emerytalnych w rozumieniu art. 119 (141) TWE. ETS, przyznając jej rację w sporze, zauważył, że w rozumieniu art. 119 TWE zasada, że mężczyźni i kobiety powinni otrzymywać jednakowe wynagrodzenie, jest jedną z podstawowych zasad Wspólnoty. Sądy mają obowiązek ochrony praw, które ten przepis (obecnie art. 157 TFUE) gwarantuje jednostkom, zwłaszcza w odniesieniu do tych form dyskryminacji, które wywodzą się bezpośrednio z postanowień ustawowych lub zbiorowych umów o pracę, jak również w sytuacjach, gdy mężczyźni i kobiety otrzymują różne wynagrodzenie za tę samą pracę wykonywaną w tym samym przedsiębiorstwie lub instytucji usługowej prywatnej lub publicznej. Tym samym art. 119 TWE (obecnie 157 TFUE) wywiera bezpośredni skutek i stwarza prawa tak dla pracowników, jak i dla pracodawców ${ }^{7}$.

Istota artykułu 157 ust. 2 TFUE związana jest z zawarciem w jego treści zasady równości wynagrodzeń dla pracowników płci męskiej i żeńskiej za taka sama pracę lub pracę takiej samej wartości. Dla celów art. 157 TFUE przez wynagrodzenie rozumie się zwykłą podstawową lub minimalną płacę albo uposażenie, a także wszelkie inne korzyści w gotówce lub w naturze otrzymywane bezpośrednio lub pośrednio od pracodawcy z racji zatrudnienia. Równość wynagrodzenia bez dyskryminacji, a zatem jednakowe wynagrodzenie za jednakowa pracę, ustala się na podstawie postanowień art. 157 ust. 2, a także dyrektyw „równościowych” i orzeczeń Trybunału Sprawiedliwości UE. Zachodzi ona wtedy, gdy:

\footnotetext{
${ }^{5}$ W. Kopaliński, Stownik wyrazów obcych, PWN, Warszawa 1998.

${ }^{6}$ J. Barcz, E. Kawecka-Wyrzykowska, K. Michałowska-Gorywoda, Integracja europejska, Warszawa 2007, s. 158 .

${ }^{7}$ Sprawa 43/75 Gabrielle Defrenne v. Sabena, Zb Orz. 1976, s. 455.
} 
- wynagrodzenie przyznane za taką samą pracę na akord jest określane na podstawie takiej samej jednostki miary, oraz gdy

- wynagrodzenie za pracę na czas jest takie samo na tym samym stanowisku.

Pojęcie wynagrodzenia, sformułowane pierwotnie w art. 141 TWE, a obecnie w art. 157 ust. 2 TFUE, zostało rozwinięte przez orzeczenia Trybunału Sprawiedliwości Unii Europejskiej - TSUE (dawniej ETS). Zgodnie z nimi składnikami wynagrodzenia są wszelkie świadczenia pracodawcy za wykonywaną pracę, w tym np. ustalanie wieku emerytalnego (sprawa 149/88, Defrenne III), świadczenia zakładowego systemu emerytalnego (sprawa Seymour C-167/97), brak obowiązku wykonywania jednakowej pracy przez kobiety i mężczyzn jednocześnie w tym samym zakładzie (sprawa 129/79 Wendy Smith). Wobec kobiet, jak i mężczyzn niedopuszczalna jest też jakakolwiek dyskryminacja pośrednia w zakresie wynagrodzenia. TSUE wskazał na to np. w sprawie C-184/89 Nimz, gdzie doszedł do przekonania, że sprzeczne $\mathrm{z}$ art. 141 (157 TFUE) jest, gdy pracownicy zatrudnieni w niepełnym wymiarze czasu pracy, np. na $1 / 2$ etatu muszą dwukrotnie dłużej pracować w danym przedsiębiorstwie, by przejść do wyższej grupy uposażeń, a także w sprawie C-171/88 Rinner-Kühn, gdzie Trybunał orzekł, że odmowa uznania ciągłości płacowej pracowników zatrudnionych w niepełnym wymiarze godzin jest sprzeczna $\mathrm{z}$ art. $141(157)^{8}$.

Postanowienia traktatowe, dotyczące zapewnienia równouprawnienia kobiet i mężczyzn w obowiązującym stanie prawnym, zostały wsparte przez zapisy Karty Praw Podstawowych oraz postanowienia poszczególnych dyrektyw przyjmowanych stopniowo od lat 70-tych XX wieku. Wskazuje na to treść art. 21 Karty, zgodnie z którym zakazana jest wszelka dyskryminacja ze względu na płeć, rasę, kolor skóry, pochodzenie etniczne lub społeczne, cechy genetyczne, język, religię lub przekonania, poglądy polityczne lub wszelkie inne poglądy, przynależność do mniejszości narodowej, majątek, urodzenie, niepełnosprawność, wiek lub orientację seksualną oraz art. 23 Karty, zgodnie z którym należy zapewnić równość kobiet i mężczyzn we wszystkich dziedzinach, w tym w zakresie zatrudnienia, pracy i wynagrodzenia ${ }^{9}$.

Postanowienia przepisów traktatowych oraz Karty Praw Podstawowych dotyczące zapewnienia równego traktowania i zakazu dyskryminacji ze względu na płeć zostały rozwinięte przez szereg dyrektyw. Proces ich przyjmowania zainicjowano w połowie lat 70-tych, czego wyrazem jest dyrektywa Rady 75/117 z 10 lutego 1975 r. w sprawie zbliżenia ustawodawstw państw członkowskich dotyczących stosowania zasady równego traktowania mężczyzn i kobiet w zakresie dostępu do zatrudnienia, kształcenia i awansu zawodowego ${ }^{10}$. Jej ustanowienie było odpowiedzią na dysproporcje płacowe, które sprawiają, że kobiety są gorzej wynagradzane za pracę tej samej wartości. Znajduje to wyraz w badaniach sondażowych przeprowadzanych wśród mieszkańców krajów UE ${ }^{11}$. Jedno z nich, sporządzone w 2009 r., wskazało, że problem „luki płacowej” (pay gap) pomiędzy kobietami a mężczyznami w Unii jest wymieniany na drugim miejscu zaraz po kwestii aktów przemocy wobec kobiet. Na znaczne (10-30\%) różnice płacowe pomiędzy kobietami a mężczyznami wskazało $50 \%$ respondentów $^{12}$, przy czym najwięcej w Szwecji (66\%), a najmniej we Włoszech (33\%) ${ }^{13}$. W tych

\footnotetext{
${ }^{8}$ F. Emmert, M. Morawiecki, Prawo europejskie, Warszawa-Wrocław 2002, s. 266.

${ }^{9}$ Karta Praw Podstawowych Unii Europejskiej (nr 2007/C 303/01) z dnia 14 grudnia 2007 r. (Dz. Urz. UE 2007 C3030), s. 1.

${ }^{10}$ Dz. Urz. WE 1975 L 45/19.

${ }^{11}$ Gender equality In the EU In 2009-summary, Special Eurobarometer 326/Wave 72.2 - TNS Opinion and Social, s. 12-17.

${ }^{12}$ Badania przeprowadzono na grupie 26470 Europejczyków z 27 krajów Unii Europejskiej.

13 Ibidem, s. 12.
} 
samych badaniach $62 \%$ Europejczyków stwierdziło, że dyskryminacja ze względu na płeć jest rozpowszechniona, pomimo że prawodawstwo unijne w tym względzie jest systematycznie rozwijane. Nic dziwnego, że dla Unii Europejskiej inwestowanie za pośrednictwem Europejskiego Funduszu Społecznego w zwiększanie uczestnictwa kobiet w rynku pracy stało się jednym z priorytetów włączonych do Strategii Lizbońskiej. Jednakże pomimo wzrostu wskaźnika zatrudnienia kobiet z 54,3\% do 57,2\% w latach 2001-2006, nie udało się osiagnąć docelowej wartości 60\% w 2010 r. Nierówności wciąż się utrzymują a kobiety nadal w niewystarczającym stopniu uczestniczą w procesach decyzyjnych w zakresie polityki i gospodarki.

W latach 70. przyjęto także dyrektywę 207/76 (z 9 lutego 1976 r.) w sprawie stosowania zasady jednakowego traktowania mężczyzn i kobiet w zakresie dostępu do zatrudnienia, awansu i szkoleń zawodowych oraz warunków pracy zmienioną dyrektywą 2002/73 WE z 23.09.2002 r. ${ }^{14}$ Przykładowo wynika z nich zakaz zadawania przez pracodawcę pytań kandydatce do pracy o to, czy jest ona w ciąży. Takie pytanie stanowi w świetle art. 2 ust. 1 i 3 dyrektywy bezpośrednią dyskryminację ze względu na płeć. W takiej sytuacji kobiecie przysługuje prawo udzielenia nieprawdziwej odpowiedzi, a pracodawca nie może wzruszyć umowy, nawet powołując się na podstępne wprowadzenie go w błąd ${ }^{15}$. Istotne były też postanowienia dyrektywy 79/7 w sprawie stopniowego urzeczywistniania zasady równego traktowania mężczyzn i kobiet w zakresie bezpieczeństwa socjalnego, zgodnie z którymi zabroniona została dyskryminacja ze względu na płeć w dostępie do ubezpieczenia społecznego ${ }^{16}$. W latach 80. ubiegłego wieku przyjęto ponadto dyrektywę 86/613/EWG w sprawie stosowania zasady równego traktowania kobiet i mężczyzn pracujących na własny rachunek, w tym w rolnictwie, oraz w sprawie ochrony kobiet pracujących na własny rachunek w okresie ciąży i macierzyństwa ${ }^{17}$. Z kolei w latach 90 . do porządku prawnego UE weszły dwa niezwykle istotne akty prawne: dyrektywa 96/34/WE z 3.06.1996 r. w sprawie porozumienia ramowego dotyczącego urlopu rodzicielskiego zawartego przez UNICE, CEEP oraz ETUC ${ }^{18}$, a także dyrektywa 97/80/WE z 15.12.1997 r. dotycząca ciężaru dowodu w sprawach dyskryminacji ze względu na płeć ${ }^{19}$. Razem z dyrektywą Rady 2004/113/WE, wprowadzającą w życie zasadę równego traktowania mężczyzn i kobiet w zakresie dostępu do towarów i usług oraz dostarczania towarów i usług, stworzyły one dość spójny system aktów prawa wtórnego, wspierający i rozwijający postanowienia TFUE.

\section{Aktywność kobiet na europejskim rynku pracy - benchmarking}

Pomimo utrzymujących się wciąż nierówności między kobietami a mężczyznami na rynku pracy w ostatnich latach wyraźnie zaznacza się tendencja do wzrostu uczestnictwa kobiet w owym rynku. Ta pozytywna zmiana stanowi ważny wkład we wzrost gospodarczy w UE, równy jednej czwartej rocznego wzrostu gospodarczego od 1995 r. ${ }^{20}$ Przeświadczenie o tym,

\footnotetext{
${ }^{14}$ Dz. Urz. WE L 269/15 z 2002 r. Por. wyrok ETS w sprawie Kalanke, C-450/93 z 7 października 1995, Zb. Orz. 1995.

${ }^{15}$ Por. Praca i zarzqdzanie kapitałem ludzkim w perspektywie europejskiej, red. A. Pocztowski, Kraków 2005, s. 88; M. Alt, M. Szponar, op. cit., s. 54.

${ }^{16}$ Temu zagadnieniu poświęcono m.in. orzeczenia w sprawach Nolte C-317/93i Megner C-444/93.

${ }^{17}$ Dz. Urz. WE 1986 L 359/56.

18 Dz. Urz. WE 1996 L 145/4.

${ }^{19}$ Dz. Urz. WE 1998 L 14/6.

${ }^{20}$ Gender and sustainable development. Maximizing the economic, social and environmental role of women, OECD, 2008.
} 
że kobiety są „systemowo" mniej aktywne na rynku pracy stopniowo podlega dezaktualizacji. Coraz sprawniej łączą one pracę zawodową $\mathrm{z}$ obowiązkami rodzinnymi, wykorzystując przy tym instrumenty charakterystyczne dla modelu flexecurity - np. umowy niestandardowe i o elastycznych standardach. Chodzi tu o umowy na czas określony, umowy o pracę w niepełnym wymiarze godzin, umowy o pracę na telefon, umowy o pracę ,zero godzin”, umowy z pracownikami zatrudnianymi przez agencje pośrednictwa pracy, umowy zlecenia itp., które stały się w ostatnich latach bardzo popularne na europejskich rynkach pracy. Według Komisji całkowity udział w zatrudnieniu osób pracujących w sposób inny niż standardowy model umowy, włącznie z osobami samozatrudnionymi, zwiększył się wśród wszystkich pracowników 25 państw UE z 36\% w 2001 r. do ok. 40\% w 2005 r.

W okresie ostatnich 15 lat z 13\% do $18 \%$ zwiększyło się też zatrudnienie w niepełnym wymiarze godzin wyrażone jako procent całkowitego zatrudnienia. Miało ono większy wkład (ok. 60\%) w tworzenie nowych miejsc pracy po roku 2000 niż standardowe zatrudnienie w pełnym wymiarze godzin. Większość osób zatrudnionych w niepełnym wymiarze godzin to kobiety. Prawie jedna na trzy kobiety pracuje aktywnie zawodowo w niepełnym wymiarze godzin, zaś w przypadku mężczyzn jest to $7 \%{ }^{21}$.

Wzrost aktywności zawodowej kobiet na europejskim rynku pracy był szczególnie widoczny w ciągu ostatniej dekady. Stopa zatrudnienia kobiet w wieku 15-64 lata wzrosła w tym czasie o 6,6 punktów procentowych, osiagając w 2009 r. poziom $58,6 \%{ }^{22}$. Warto jednak zauważyć, że różni się on znacząco w poszczególnych państwach członkowskich i waha od 37,7\% (Malta) do 73,1\% (Dania). Średnia różnica między stopą zatrudnienia kobiet i mężczyzn zmniejszyła się z 18,2\% w 1998 r. do $13,7 \%$ w $2008^{23}$. Tę pozytywną tendencję przerwał jednak kryzys gospodarczy, który bardzo poważnie wpłynął na dane liczbowe dotyczące rynku pracy i bezrobocia.

Założone w Strategii Lizbońskiej wskaźniki zatrudnienia kobiet i osób w wieku 55-64 lata nie zostały osiagnięte. Jak już wspomniano, wskaźnik zatrudnienia kobiet w wieku 15-64 lata w 2009 r. na obszarze UE-27 wyniósł 58,6\% (w strefie euro - 58,3\%), przy czym w dalszym ciagu widoczna jest $\mathrm{w}$ tym zakresie znaczna dysproporcja $\mathrm{w}$ porównaniu $\mathrm{z}$ aktywnością mężczyzn, których stopa zatrudnienia w 2009 r. osiągnęła poziom $70,7 \%(71,2 \% \mathrm{w} \text { strefie euro })^{24}$. Podobnie kształtowała się sytuacja pracowników w przedziale wiekowym 55-64 lata. Całkowita stopa zatrudnienia osób w tym wieku na obszarze UE-27 wyniosła 46\% w 2009 r., przy czym pod względem aktywności zawodowej przeważali mężczyźni $(54,8 \%)$, podczas gdy jedynie 37,8\% kobiet znalazło zatrudnienie.

Według danych Eurostatu w 2009 r. najwyższy wskaźnik zatrudnienia kobiet w wieku 15-64 lata odnotowano w Danii (73,1\%), Holandii (71,5\%) Szwecji (70,2\%), i Finlandii $(67,9 \%)$. Z kolei najniższy poziom aktywności zawodowej kobiet zaobserwowano głównie na Malcie (37,7\%), w krajach południowych (Włochy - 46,4\%, Grecja - 48,9\%) i nowych państwach członkowskich UE (Węgry - 49,9\%, Polska - 52,8\%, Słowacja-52,8\%, Rumunia

${ }^{21}$ Zielona Księga, Modernizacja prawa pracy w celu sprostania wyzwaniom XXI wieku, Komisja Europejska KOM (2006) 708 wersja ostateczna, Bruksela, 22.11.2006, s. 8.

$22 \mathrm{http} / /$ epp.eurostat.ec.europa.eu/tgm/table.do?tab=table\&init=1\&plugin=1\&language=en \&pcode=tsiem010, odczyt z dnia 7.02.2011 r.

${ }^{23}$ Równość kobiet i mężczyzn - rok 2010, Sprawozdanie Komisji dla Rady, Parlamentu Europejskiego, Europejskiego Komitetu Ekonomiczno-Społecznego i Komitetu Regionów KOM(2009)694 wersja ostateczna, Bruksela, dnia 18.12.2009, s. 4.

${ }^{24}$ Key figures on Europe, Eurostat pocketbooks, Komisja Europejska, 2010, s. 91; http://epp.eurostat.ec.europa.eu/tgm/table.do?tab=table\&init=1\&plugin=1\&language=en\&pcode=tsiem010, odczyt z dnia 7.02.2011 r. 
52\%). W badanym okresie łącznie 14 krajów spełniło lizbońską wartość docelową $60 \%$ zatrdnienia kobiet ${ }^{25}$, co oznacza, że w od 2005 r. osiagnięto nieznaczny postęp ${ }^{26}$.

Tabela 1

Stopa zatrudnienia kobiet w krajach Unii Europejskiej w latach 2000-2009

\begin{tabular}{|c|c|c|c|c|}
\hline Kraje/Rok & 2000 & 2005 & 2008 & 2009 \\
\hline UE 27 & 53,7 & 56,3 & 59,1 & 58,6 \\
\hline Strefa Euro (16 krajów) & 51,7 & 55,6 & 58,7 & 58,3 \\
\hline Austria & 59,6 & 62,0 & 65,8 & 66,4 \\
\hline Belgia & 51,5 & 53,8 & 56,2 & 56,0 \\
\hline Bułgaria & 46,3 & 51,7 & 59,5 & 58,3 \\
\hline Cypr & 53,5 & 58,4 & 62,9 & 62,5 \\
\hline Czechy & 56,9 & 56,3 & 57,6 & 56,7 \\
\hline Dania & 71,6 & 71,9 & 73,9 & 73,1 \\
\hline Estonia & 56,9 & 62,1 & 66,3 & 63,0 \\
\hline Finlandia & 64,2 & 66,5 & 69,0 & 67,9 \\
\hline Francja & 55,2 & 58,4 & 60,4 & 60,0 \\
\hline Grecja & 41,7 & 46,1 & 48,7 & 48,9 \\
\hline Hiszpania & 41,3 & 51,2 & 54,9 & 52,8 \\
\hline Holandia & 63,5 & 66,4 & 71,1 & 71,5 \\
\hline Irlandia & 53,9 & 62,1 & 66,3 & 63,0 \\
\hline Litwa & 57,7 & 59,4 & 61,8 & 60,7 \\
\hline Luksemburg & 50,1 & 53,7 & 55,1 & 57,0 \\
\hline Łotwa & 53,8 & 59,3 & 65,4 & 60,9 \\
\hline Malta & 33,1 & 33,7 & 37,4 & 37,7 \\
\hline Niemcy & 58,1 & 60,6 & 65,4 & 66,2 \\
\hline Polska & 48,9 & 46,8 & 52,4 & 52,8 \\
\hline Portugalia & 60,5 & 61,7 & 62,5 & 61,6 \\
\hline Rumunia & 57,5 & 51,5 & 52,5 & 52,0 \\
\hline Słowacja & 51,5 & 50,9 & 54,9 & 52,8 \\
\hline Słowenia & 58,4 & 61,3 & 64,2 & 63,8 \\
\hline Szwecja & 70,9 & 70,4 & 71,8 & 70,2 \\
\hline Węgry & 49,7 & 51,0 & 50,6 & 49,9 \\
\hline Wielka Brytania & 64,7 & 65,8 & 65,8 & 65,0 \\
\hline Włochy & 39,6 & 45,3 & 47,2 & 46,4 \\
\hline
\end{tabular}

Źródło: http://epp.eurostat.ec.europa.eu, odczyt z dnia 8.02.2011 r.

Warto zauważyć, że kryzys finansowy spowodował zahamowanie pozytywnych tendencji w zakresie zatrudnienia kobiet na europejskim rynku pracy. W większości krajów UE stopa

${ }^{25}$ Dania, Niemcy, Estonia, Francja, Cypr, Litwa, Łotwa, Holandia, Austria, Portugalia, Słowenia, Finlandia, Szwecja, Wielka Brytania.

${ }^{26}$ Wówczas w 13 krajach osiągnięto powyższy cel. 
zatrudniania tej grupy w 2009 r. zmniejszyła się w porównaniu z 2008 rokiem. Co więcej, jak pokazuje doświadczenie z poprzednich kryzysów, zatrudnienie mężczyzn zasadniczo wraca do poprzedniego poziomu szybciej niż zatrudnienie kobiet. Także w przypadku osób, które straciły pracę, ryzyko, że nie znajdą nowego zatrudnienia, jest wyższe wśród kobiet. Poświęcenie szczególnej uwagi tej kwestii jest ważne, zwłaszcza, że kobiety stanowią ponad dwie trzecie spośród 63 milionów osób nieaktywnych zawodowo w UE w wieku od 25 do 64 lat lub wśród osób częściowo bezrobotnych (osób zatrudnionych w niepełnym wymiarze czasu pracy, a chcących pracować w większym wymiarze), które nie zawsze są zarejestrowane jako bezrobotne $^{27}$. W przypadku kobiet istnieje większe prawdopodobieństwo znalezienia się w niekorzystnej sytuacji na rynku pracy, co negatywnie wpływa na ich dochody w okresie całego życia, zabezpieczenie społeczne i emerytury, prowadząc do wyższego wskaźnika zagrożenia ubóstwem, w szczególności po przejściu na emeryturę. W 2007 r. wskaźnik zagrożenia ubóstwem był wyższy w przypadku kobiet (17\%) niż u mężczyzn (15\%), a różnica ta była szczególnie wysoka wśród osób starszych (22\% w przypadku kobiet w porównaniu z 17\% w przypadku mężczyzn) i rodziców samotnie wychowujących dzieci ${ }^{28}$. Warto zauważyć, że utrata pracy przez kobietę znajdującą się w gospodarstwie domowym opartym na tradycyjnym modelu mężczyzny jako ,żywiciela rodziny” (male-breadwinner model) znacząco pogarsza jej kondycję psychiczną i obniża standard życia, jak również negatywnie przekłada się na życie poszczególnych rodzin (zwłaszcza gdy pracę traci również mężczyzna). $Z$ tego też względu potrzebne jest dalsze wspieranie modelu, w którym gospodarstwo domowe utrzymują dwie osoby.

Do przyczyn utrudniających kobietom aktywność zawodową można zaliczyć swoistą „segmentację" kobiet na rynku pracy wyrażającą się podejmowaniem przez nie kształcenia, a następnie świadczenie pracy w sektorach uznawanych za tradycyjnie „kobiece” (np. usługi zdrowotne, edukacja), zazwyczaj mniej opłacalnych niż sektory zajmowane głównie przez mężczyzn. Problem stanowi też zajmowanie przez kobiety relatywnie małej liczby odpowiedzialnych stanowisk we wszystkich sferach społecznych. Szczególnie potrzebny wydaje się być wzrost liczby kobiet uczestniczących w procesach decyzyjnych lub wyznaczanych na stanowiska decyzyjne oraz w sferze gospodarczej i politycznej, gdzie władza pozostaje niezmiennie w rękach mężczyzn.

Powyższa problematyka wymaga krótkiego rozwinięcia, bowiem mimo wszystko w ostatnich latach coraz więcej kobiet zajmuje wysokie stanowiska w polityce i gospodarce. Pomimo że kobiety stanowią tam wciąż mniejszość, to coraz głośniej domagają się przyznania należnych im praw. Świadczą o tym dane, z których wynika, że liczba kobiet w legislaturach krajowych w UE wzrosła z 16\% w 1997 roku do 24\% w 2007 r. Stosunkowo najlepszy wynik osiagnęły one w krajach nordyckich, zwłaszcza w Finlandii (42\% miejsc w parlamencie) i Szwecji $(47 \%)^{29}$. Podobnie wygląda wskaźnik uczestnictwa kobiet w rządach poszczególnych krajów członkowskich UE. W drugiej połowie lat 90. ubiegłego wieku ich liczba w egzekutywach wzrosła z $16 \%$ do $24 \%$. Wart uwagi jest przy tym fakt, że kobiety po raz pierwszy uzyskały większość w socjaldemokratycznym gabinecie José Luisa Rodrígueza Zapatero, co można uznać za ich duży sukces, zważywszy na tradycyjnie konserwatywny obraz Hiszpanii jako południowoeuropejskiego kraju zdominowanego przez męską kulturę

\footnotetext{
${ }^{27}$ Report on equality between women and men 2010, European Commission, Luxembourg 2010, s. 8.

${ }^{28}$ Ibidem.

${ }^{29}$ Where are the women in politics? Despite huge progress in the area of gender equality, men still call the shots in the political world, ,Social Agenda”, October 2008, s. 7.
} 
machismo $^{30}$ wyrażającą się w kulcie męskości i deprecjonowaniu roli kobiet w sferze polityczno-gospodarczej ${ }^{31}$. Co więcej, kobiety w rządzie Zapatero uzyskały stanowiska tradycyjnie zarezerwowane dla mężczyzn (np. resort obrony), wychodząc poza zazwyczaj obsadzane przez nie urzędy w takich dziedzinach, jak sprawy społeczne, edukacja, środowisko.

O ile coraz więcej kobiet uczestniczy na ,politycznym rynku pracy”, pełniąc odpowiedzialne funkcje, o tyle wciąż bardzo niewiele $\mathrm{z}$ nich zajmuje najwyższe pozycje w państwach lub też w UE. Warto w tym aspekcie wspomnieć, że pierwszym krajem członkowskim UE, w którym kobieta objęła stanowisko przewodniczącego krajowej legislatury była Austria. W 1927 roku stanowisko przewodniczącego Bundesratu zajęła Olga Rudel-Zeynek. Trzeba było jednak czekać do 1950 r., kiedy to kolejna kobieta stanęła na czele parlamentu. Swoisty przełom w tym zakresie nastapił dopiero w latach 90. Wskazuje na to fakt, że w latach 1990-1999 dziewięć kobiet wybrano na przewodniczące parlamentów krajowych, podczas gdy w latach 1927-1989 jedynie siedem z nich znalazło się na tak wysokim stanowisku ${ }^{32}$. Na poziomie europejskim jedynie dwie kobiety przewodniczyły Parlamentowi Europejskiemu. W latach 1979-1982 rola ta przypadła Simone Veil, a w kadencji 1999-2002 - Nicole Fontaine ${ }^{33}$.

Jeszcze trudniej jest kobietom pokonać mężczyzn w wyścigu do najwyższych stanowisk w krajowych egzekutywach oraz ciałach ponadnarodowych w UE, takich jak Komisja czy Trybunał Sprawiedliwości. Spośród 20 krajów Unii Europejskiej, których konstytucje przewidują stanowisko prezydenta, tylko Mary McAleese z Irlandii oraz Tarja Halonen z Finlandii piastowały w 2008 r. urząd głowy państwa. Jedynym zaś szefem rządu była niemiecka kanclerz Angela Merkel przewyższająca zresztą swoich kolegów z innych krajów członkowskich wykształceniem (posiada stopień naukowy doktora).

Znacznie lepsza sytuacja w zakresie aktywności zawodowej występuje na poziomie UE. Dla przykładu liczba eurodeputowanych, będących kobietami, znacząco wzrosła z 17\% w 1984 roku do 35\% w 2009 roku. Pozytywne zmiany zachodzą też w Komisji Europejskiej, która już po raz drugi kieruje Jose Manuel Barroso. Do jej składu na lata 2010-2014 weszło 10 kobiet. Jest to - co prawda - tyle samo, co w Komisji poprzedniej kadencji, jednakże kobiety objęły $3 \mathrm{z}$ siedmiu stanowisk wiceprzewodniczących Komisji ${ }^{34}$, podczas gdy poprzednio tylko Margot Wallström ze Szwecji dane było sprawować tę funkcję.

Jak widać, mimo powolnych zmian, kobiety wciąż znacząco ustępują mężczyznom na najwyższych stanowiskach w krajach członkowskich oraz samej Unii Europejskiej. W UE średnio zaledwie jeden na czterech członków parlamentów narodowych i ważniejszych ministrów rządów krajowych jest kobietą, chociaż sytuacja ta różni się w poszczególnych państwach członkowskich. W sektorze gospodarczym dane liczbowe przedstawiają jeszcze mniej pozytywny obraz. Kobiety stanowią na przykład zaledwie jedną dziesiątą członków zarządów najważniejszych europejskich przedsiębiorstw oraz 3\% wśród prezesów zarządów. Zjawisko blokowania dostępu kobiet do atrakcyjnej, perspektywicznej pracy wzbudza uzasadniony protest. Coraz częściej odrzuca się zarówno polityczne, jak i kulturowe argumenty przeciwko zmniejszeniu roli kobiet w życiu publicznym, słusznie uznając je za objaw dyskry-

\footnotetext{
${ }^{30}$ Od słowa macho - samiec.

${ }^{31}$ Por. J. Bryła, Stosunki międzynarodowe na pótkuli zachodniej, w: Stosunki międzynarodowe, red. W. Malendowski, Cz. Mojsiewicz, Wrocław 2004, s. 165-166.

${ }^{32}$ Where are the women..., op. cit., s. 8.

${ }^{33}$ Obie są Francuzkami.

${ }^{34}$ Do kobiet pełniących funkcję wiceprzewodniczących Komisji Europejskiej obecnej kadencji zalicza się: Catherine Ashton z Wielkiej Brytanii (Wysoki przedstawiciel ds. zagranicznych i polityki bezpieczeństwa Unii europejskiej), Viviane Reding (Sprawiedliwość, prawa podstawowe i obywatelstwo), Neelie Kroes (Agenda cyfrowa).
} 
minacji. Jak stwierdziła była komisarz Margot Wallström - mała liczba kobiet w polityce jest przejawem funkcjonowania w Europie „męskiego kartelu” (male cartel). Problem - jej zdaniem - nie leży w niewystarczającej liczbie zdolnych kobiet, ale wynika z praktyki, w której mężczyźni wybieraja mężczyzn ${ }^{35}$.

Blokowanie dostępu kobiet do wyższych stanowisk w polityce i biznesie oraz podejmowanie przez nie kształcenia, a następnie świadczenie pracy w sektorach mało atrakcyjnych płacowo to nie jedyne przyczyny relatywnie dużego bezrobocia wśród kobiet. Palącą kwestię stanowi brak dostępu do usług w zakresie opieki dla osób, które jej wymagają (dzieci, osoby niepełnosprawne, osoby starsze), odpowiednich systemów urlopowych i elastycznych form zatrudnienia dla obojga rodziców, co często utrudnia kobietom uczestniczenie w rynku pracy lub podjęcie pracy w pełnym wymiarze czasu pracy. W $2008 \mathrm{r}$. w niepełnym wymiarze czasu pracy pracowało $31,1 \%$ kobiet w porównaniu z 7,9\% mężczyzn. Biorąc pod uwagę stopę zatrudnienia w pełnym wymiarze czasu pracy, od 2003 r. różnica w traktowaniu kobiet i mężczyzn zmniejszyła się tylko nieznacznie, a w dziewięciu państwach członkowskich nawet wzrosła $^{36}$. Warto też zauważyć korelację pomiędzy rodzicielstwem, a uczestnictwem na rynku pracy kobiet i mężczyzn. Kobiety posiadające dzieci pracują mniej (stopa zatrudnienia niższa o 11,5 punktów procentowych) w porównaniu z kobietami nieposiadającymi dzieci, podczas gdy mężczyźni posiadający dzieci pracują więcej niż mężczyźni nieposiadający ich (stopa zatrudnienia wyższa o 6,8 punktów procentowych). Chociaż w ciągu ostatnich kilku lat, zgodnie z celami europejskimi, odnotowano wzrost dostępności opieki nad dziećmi, to jednak w wielu krajach wskaźniki objęcia dzieci odpowiednią opieką utrzymują się na poziomie niższym niż poziom docelowy, w szczególności w przypadku dzieci poniżej 3 roku życia.

Warto zauważyć, że rozwój opieki instytucjonalnej nad dziećmi znalazł się w sferze szczegółowego zainteresowania w roku 2002, podczas określania kierunków realizacji strategii zatrudnienia w trakcie obrad Rady Europejskiej w Barcelonie. Ustalono wtedy, że do roku 2010 z usług opieki pozarodzinnej powinno korzystać 33\% dzieci w wieku do 3 lat oraz $90 \%$ populacji od 3 lat do wieku obowiązkowej nauki w szkole ${ }^{37}$. Również w Polsce, w ramach Narodowej Strategii Integracji Społecznej ${ }^{38}$, a także w dokumencie Założenia polityki ludnościowej, zostały poczynione ustalenia zgodnie z powyższym standardem. W odniesieniu do przedszkoli określone zamierzenia zostały zawarte w Strategii Rozwoju Edukacji na lata 2007-201339. Zapewnienie większej niż do tej pory opieki nad dziećmi jest z punktu widzenia zatrudnienia kobiet działaniem priorytetowym. O ile bowiem w UE z opieki publicznych placówek opieki nad dziećmi korzysta 70-80\% dzieci w wieku 3-5 lat, o tyle w Polsce tylko około $20 \%{ }^{40}$.

Analizując przyczyny zmniejszonej aktywności zawodowej kobiet na europejskim rynku pracy, nie można też zapominać o wspomnianym już szkodliwym zjawisku segregacji płci (ang. gender segragation). Wyrażenie to zostało wprowadzone do debaty akademickiej w latach 60. ubiegłego wieku i wyraża się w równym (nierównym) traktowaniu kobiet w zakresie dostępu do poszczególnych zawodów (ang. segmentation in the labour market) oraz występo-

${ }^{35}$ Where are the women..., op. cit., s. 9.

${ }^{36}$ Równość kobiet i mężczyzn - rok 2010, op. cit., s. 5.

${ }^{37}$ D. Głogosz, Instytucje opieki nad dziećmi w krajach Unii Europejskiej. Wskazania dla Polski, „Polityka Społeczna” 2004, nr 9, s. 21.

${ }^{38}$ Narodowa Strategia Integracji Społecznej dla Polski, Zespół Zadaniowy ds. Reintegracji Społecznej, Warszawa 2004 , s. 64-65.

${ }^{39}$ Ministerstwo Edukacji Narodowej i Sportu, Strategia rozwoju edukacji na lata 2007-2013, Warszawa 2005, S. $31-32$.

${ }^{40}$ Por. M. Muczyński, M. Żynel, Ewaluacja strategii uelastycznienia przedszkoli i żłobków, Białystok 2008, s. 14. 
waniu różnic w zakresie wynagrodzenia (ang. gender pay gap). Towarzyszy temu nagromadzenie stereotypów na temat roli kobiet w życiu zawodowym. Kobiety wykonują zazwyczaj słabiej płatne i cieszące się mniejszy prestiżem zawody niż mężczyźni, co obrazuje tabela 2.

Zawody w największej mierze wykonywane przez kobiety i mężczyzn w Europie w 2005 r.

\begin{tabular}{||l|l||}
\hline \multicolumn{1}{|c|}{ Kobiety } & \multicolumn{1}{c||}{ Mężczyźni } \\
\hline 1. Sprzedawczyni & 1. Kierowca \\
\hline 2. Sprzątaczka & 2. Pracownik fizyczny (zwłaszcza na budowie) \\
\hline 3. Opiekunka (np. osób starszych) & 3. Menadżer w małej firmie \\
\hline 4. Urzędniczka & 4. Handlowiec \\
\hline 5. Sekretarka & 5. Inżynier/technik \\
\hline 6. Kelnerka/barmanka & 6. Mechanik \\
\hline
\end{tabular}

Źródło: The life of women and men in Europe. A statistical portrait, Eurostat 2008, s. 59.

Towarzyszą temu różnice $\mathrm{w}$ zarobkach pomiędzy mężczyznami a kobietami w różnych krajach UE, choć w tym aspekcie różnice powoli ulegają zmniejszeniu. W 2006 roku luka płacowa, mierzona jako różnica pomiędzy przeciętnymi stawkami wynagrodzenia za godzinę pracy brutto pomiędzy mężczyznami a kobietami w przedsiębiorstwach zatrudniających dziesięć i więcej osób w 2006 roku wyniosła 17,7\%, a w 2008 - 17,5\%. Uwzględnienie długotrwałych tendencji płacowych na rynku pracy w latach 2002-2009 pozwala stwierdzić, że w wielu krajach UE postęp w zakresie redukcji wspomnianej luki płacowej był bardzo duży. Dla przykładu w 2002 roku kobiety w Rumunii, Słowacji i Wielkiej Brytanii zarabiały odpowiednio o $16 \%, 27,7 \%$ oraz $27,3 \%$ mniej niż mężczyźni na tych samych miejscach pracy. W 2009 r. dysproporcje te w powyższych krajach zmniejszyły się do 8,1\%, 21,9\% i 20,4\% ${ }^{41}$. Tendencja ta nie występuje jednakże we wszystkich krajach UE. Dla przykładu w okresie 2002-2009 luka płacowa w Czechach i Litwie wzrosła z odpowiednio z 22,1\% i 13,2\% do $25,9 \%$ i $15,3 \%$.

Warto zauważyć, że pomimo szeregu trudności ograniczających aktywność kobiet na rynku pracy w Unii Europejskiej w dobie kryzysu, radzą one sobie w wielu przypadkach lepiej niż mężczyźni. Świadczą o tym dane przedstawione w tabeli 3.

Stopa bezrobocia kobiet i mężczyzn w krajach Unii Europejskiej w latach 2005-2010.

\begin{tabular}{||l|c|c|c|c||}
\hline \multicolumn{1}{|c|}{ Rok } & \multicolumn{2}{c|}{$\mathbf{2 0 0 5}$} & \multicolumn{2}{c||}{$\mathbf{2 0 1 0}$} \\
\hline \multicolumn{1}{|c|}{ Kobiety(K)/mężczyźni(M) } & K & M & K & M \\
\hline UE 27 & 2 & 3 & 4 & 5 \\
\hline Strefa Euro (16 krajów) & 9,6 & 8,3 & 9,5 & 9,7 \\
\hline Austria & 10,1 & 8,2 & 10,1 & 9,9 \\
\hline Belgia & 5,5 & 4,9 & 4,2 & 4,9 \\
\hline Bułgaria & 9,5 & 7,6 & 8,6 & 8,2 \\
\hline \hline
\end{tabular}

\footnotetext{
${ }^{41} \mathrm{http}: / /$ epp.eurostat.ec.europa.eu/tgm/table.do?tab=table\&init=1\&plugin=1\&language=en \&pcode=tsiem040, odczyt z dn. 8.02.2011 r.
} 


\begin{tabular}{|l|c|c|c|c||}
\hline \multicolumn{1}{|c|}{1} & 2 & 3 & 4 & 5 \\
\hline Cypr & 6,5 & 4,3 & 6,9 & 6,6 \\
\hline Czechy & 9,8 & 6,5 & 8,6 & 6,5 \\
\hline Dania & 5,3 & 4,4 & 6,7 & 8,3 \\
\hline Estonia & 7,1 & 8,8 & - & - \\
\hline Finlandia & 8,6 & 8,2 & 7,6 & 9,1 \\
\hline Francja & 10,3 & 8,4 & 10,0 & 9,5 \\
\hline Grecja & 15,4 & 6,1 & - & - \\
\hline Hiszpania & 12,2 & 7,1 & 20,5 & 19,7 \\
\hline Holandia & 5,8 & 4,9 & 4,5 & 4,4 \\
\hline Irlandia & 4,1 & 4,6 & 9,5 & 16,6 \\
\hline Litwa & 8,3 & 8,2 & - & - \\
\hline Luksemburg & 6,0 & 3,6 & 5,4 & 4,1 \\
\hline Łotwa & 8,7 & 9,1 & - & - \\
\hline Malta & 8,9 & 6,4 & 7,1 & 6,5 \\
\hline Niemcy & 10,1 & 11,2 & 6,2 & 7,4 \\
\hline Polska & 19,2 & 16,6 & 10,1 & 9,4 \\
\hline Portugalia & 8,8 & 6,8 & 12,1 & 9,9 \\
\hline Rumunia & 6,4 & 7,8 & - & - \\
\hline Słowacja & 17,2 & 15,5 & 14,6 & 14,4 \\
\hline Słowenia & 7,1 & 6,2 & 7,0 & 7,4 \\
\hline Szwecja & 7,6 & 7,7 & 8,2 & 8,5 \\
\hline Węgry & 7,4 & 7,0 & 10,7 & 11,7 \\
\hline Wielka Brytania & 4,3 & 5,2 & - & - \\
\hline Włochy & 10,1 & 6,2 & - & - \\
\hline \hline
\end{tabular}

Źródło: http://epp.eurostat.ec.europa.eu/tgm/table.do?tab=table\&init=1\&plugin=1\&language=en\&pcode=tsiem110, odczyt z dnia 8.02.2011 r.

Najwyższymi stopami bezrobocia kobiet w badanym okresie charakteryzowały się: Polska (19,2\% w 2005 r. i 10,1\% w 2010 r.), Słowacja (17,2\% w 2005 r. i 14,6\% w 2010 r.), Hiszpania (12,2\% w 2005 r. i 20,5\% w 2010 r.), a także Grecja i Portugalia. Warto zauważyć, że są to kraje, których społeczeństwa tradycyjnie postrzegane są w Europie jako konserwatywne, w których jeszcze w latach 80 . rozpowszechniony był patriarchalny model rodziny. Z kolei najmniejsze bezrobocie w badanym okresie zanotowano w Danii (5,3\% w 2005 r. i 6,7\% w 2010 r.), Austrii (5,5\% w 2005 r. i 4,2\% w 2010 r.), Holandii (5,8\% w 2005 r. i 4,5\% w 2010 r.), a także w Wielkiej Brytanii i Luksemburgu. Ciekawy jest przypadek Irlandii, w której bezrobocie kobiet pomiędzy 2005 a 2010 rokiem wzrosło z 4,1\% do 9,5\%.

Interesująco przedstawiają się też wnioski wynikające z porównania stopy bezrobocia mężczyzn i kobiet. W 2005 r. bezrobocie wśród kobiet było wyższe niż u mężczyzn o 1,5 pkt procentowego. Tylko w 8 krajach UE (liczonej w obecnym składzie 27 państw) stopa bezrobocia kobiet była niższa od stopy zatrudnienia mężczyzn. Odmienna sytuacja nastąpiła w 2010 r. (dane za pierwszy kwartał). Pomimo niepełnych danych za ten okres warto zauważyć, że stopa bezrobocia kobiet była niższa od stopy bezrobocia mężczyzn o 0,2 pkt proc., co jest tym bardziej interesujące, że w 2004 r. statystyki przemawiały na niekorzyść kobiet o 2,2 pkt proc. Co ważne, coraz skuteczniej opierają się one bezrobociu zarówno w krajach 
„starej” jak i „,nowej” Europy. Świadczy o tym fakt, że do krajów, w których w 2010 r. stopa bezrobocia kobiet była niższa niż stopa bezrobocia mężczyzn, należą: Austria, Bułgaria, Dania, Finlandia, Irlandia, Niemcy, Słowenia, Szwecja i Węgry.

\section{Wyzwania i kierunki polityki w zakresie poprawy sytuacji kobiet na rynku pracy $w$ UE}

Zwiększenie aktywności kobiet na rynku pracy w dobie obecnego kryzysu można uznać za jeden z priorytetów polityki społecznej Unii Europejskiej na najbliższe lata. Pomimo pozytywnych sygnałów związanych np. ze stopniowym zmniejszaniem luki płacowej pomiędzy kobietami a mężczyznami oraz zmniejszeniem stopy bezrobocia kobiet, wiele pozostaje jeszcze do zrobienia. Bardzo ważna w tym aspekcie jest walka ze stereotypami, których rozpowszechnianie w społeczeństwach europejskich prowadzi często do negowania zasady równouprawnienia płci. Przykładem jest postrzeganie kobiet w środowisku akademickim. Można postawić tezę, że stereotypy pokutujące wśród nauczycieli akademickich, zwłaszcza średniego i wyższego szczebla (doktorów i profesorów), przyczyniają się do spowolnienia awansu zawodowego kobiet, a często nawet podważania ich dokonań zawodowych (dorobku naukowego) i wykluczenia z ciał decyzyjnych na ich rodzimych uczelniach. Niewielką w porównaniu do mężczyzn liczbę kobiet, które uzyskują tytuł naukowy profesora, tłumaczy się przy tym najczęściej brakiem posiadania przez nie niezbędnych kwalifikacji lub nadmierną koncentracją kobiet-badaczy wokół wybranych specjalizacji, określanych mianem ,,przedmiotów kobiecych" (ang. female-dominated subjects) ${ }^{42}$. Warto jednakże podkreślić, że wbrew powszechnemu przekonaniu, badania przeprowadzone na uczelniach niemieckich wykazały, że nie występuje korelacja pomiędzy koncentracją kobiet w określonych dziedzinach (np. nauki humanistyczne), a uzyskiwaniem przez nie większej liczby tytułów profesora. Co więcej, szanse na uzyskanie tego tytułu są mniejsze na kierunkach zdominowanych przez kobiety. Wskazują na to dane, z których wynika, że o ile od 1984 roku średnio 12 mężczyzn na 1000 absolwentów uczelni w Niemczech zostaje profesorami, o tyle tak znaczny awans zawodowy osiągaja jedynie cztery kobiety (dane dla wszystkich kierunków studiów). W zakresie kierunków inżynieryjnych proporcje także przemawiają na korzyść mężczyzn -8 z nich na 1000 absolwentów uzyskuje tytuł profesora wobec 6 kobiet, podczas gdy w naukach humanistycznych, gdzie liczba kobiet jest znacznie większa, tytuł profesorski uzyskało 21 mężczyzn wobec tylko 4 kobiet na 1000 absolwentów ${ }^{43}$. Wolniejsza kariera akademicka u kobiet w ,przedmiotach kobiecych” została też dostrzeżona w Belgii, gdzie duża liczba kobiet na studiach pierwszego stopnia nie przekładała się na znaczną liczbę doktoratów ${ }^{44}$.

Na skomplikowaną sytuację kobiet na europejskich uniwersytetach wskazują dane zebrane przez F. Bettio, A. Verashchaginę, J. De Henau i D. Meulders. W 2001 r. w Belgii na uniwersytetach zatrudniano $\mathrm{w}$ pełnym wymiarze czasu pracy 14\% kobiet, przy czym wśród profesorów kobiety stanowiły jedynie $8 \%$ grupę. A oto wyliczenia przeprowadzone przez

\footnotetext{
${ }^{42}$ F. Bettio, A. Verashchagina, Gender segregation in the labour market, European Commission, 2009, s. 65.

${ }^{43}$ F. Maier (A. H. Carl research assistance), Gender segregation in the labour market: root causes, implications and policy responses in Germany, 2008.

${ }^{44} \mathrm{~J}$. De Henau, Gender role attitudes, work decisions and social policies in Europe - A series of empirical essays, doctoral thesis under the direction of Prof. D. Meulders (Université Libre de Bruxelles), 2006.
} 
wskazanych badaczy, którzy wzięli pod uwagę dynamikę wzrostu reprezentacji kobiet na belgijskich uniwersytetach w ciagu ostatnich piętnastu lat:

- wyrównanie liczby kobiet i mężczyzn na stanowisku adiunkta na belgijskich uniwersytetach nastąpi nie wcześniej niż za 40 lat;

- wyrównanie liczby kobiet i mężczyzn na stanowiskach pracowników naukowo-dydaktycznych, poza stanowiskiem profesora, nastapi nie wcześniej niż za 70 lat;

— wyrównanie liczby kobiet i mężczyzn na stanowisku profesora nastąpi nie wcześniej niż za 183 lata.

Dane te pokazują bardzo pesymistyczny obraz szkolnictwa wyższego w kraju UE uznawanym za liberalny. Zmianę tej sytuacji utrudniają dodatkowo rozliczne stereotypy dotyczące kobiet. Przykładowo najbardziej rozpowszechniony z nich zawiera się w stwierdzeniu, że kobiety są mniej wydajne w zakresie prowadzenia badań i publikacji ich wyników ze względu na zobowiązania rodzinne (małżeństwo, dzieci). Badania, które zostały przeprowadzone w środowisku wykładowców na kierunkach ekonomicznych we Włoszech w latach 90. nie potwierdziły prawdziwości tego stwierdzenia ${ }^{45}$.

Rozliczne problemy ukazane powyżej dotyczą przede wszystkim zapewnienia równości kobiet i mężczyzn na rynkach pracy. Równość płci jest nie tylko kwestią różnorodności i sprawiedliwości społecznej, ale także warunkiem wstępnym do osiagnięcia celów trwałego wzrostu gospodarczego, zatrudnienia, konkurencyjności i spójności społecznej. Nic dziwnego, że UE zdecydowała się zainwestować w politykę na rzecz równości płci. Sukces na tym polu może zaprocentować wyższą stopą zatrudnienia kobiet, wyższym udziałem kobiet w PKB, dochodami podatkowymi i trwałymi wskaźnikami dzietności ${ }^{46}$. Równość płci, stając się podstawowym elementem strategii Europa 2020, jest postrzegana jako długoterminowa inwestycja, a nie jako krótkoterminowy koszt, choć istnieje ryzyko, że obecna recesja gospodarcza opóźni rozwój lub nawet zaprzepaści postęp, niosąc ze sobą długoterminowe konsekwencje dla zrównoważonego charakteru gospodarki i systemów zabezpieczenia społecznego, włączenia społecznego i demografii.

W ramach wzmacniania synergii pomiędzy równością płci i zatrudnieniem w celu pobudzenia ożywienia i trwałego wzrostu gospodarczego UE proponuje następujące działania ${ }^{47}$ :

- usuwanie utrzymujących się nierówności między kobietami i mężczyznami poprzez politykę na rzecz równości płci w celu wykorzystania pełnej potencjalnej podaży pracy, zwłaszcza w perspektywie przyszłych niedoborów wykwalifikowanych pracowników;

— reformowanie systemów podatkowych i systemów świadczeń socjalnych w celu dostarczania kobietom i mężczyznom zachęt finansowych do podejmowania i utrzymywania pracy oraz powrotu do niej;

— ułatwienie kobietom i mężczyznom godzenia życia zawodowego, prywatnego i rodzinnego poprzez zwiększenie możliwości pogodzenia życia zawodowego z obowiązkami rodzinnymi (zwłaszcza przez skłonienie mężczyzn do podejmowania liczniejszych obowiązków rodzinnych i opiekuńczych oraz rozwoju dostępnych, przystępnych cenowo i oferujących usługi wysokiej jakości ośrodków opieki nad dziećmi);

- przeciwdziałanie ubóstwu kobiet znajdujących się w trudnej sytuacji, takich jak: samotne matki, samotne starsze kobiety, kobiety niepełnosprawne, jak również kobiety

${ }^{45}$ A. Carabelli, D. Parisi, A. Rosselli, Che genere di economista: una ricerca sulla professione di economista nell'università italiana, Il Mulino (Collana S.I.E.), Bologna 1999.

${ }^{46}$ M. Smith M. F. Bettio, Analysis Note: The economic case for gender equality, EGGE, 2008.

${ }^{47}$ Report on equality..., op. cit., s. 11-14. 
wywodzące się z grup migracyjnych i mniejszości etnicznych poprzez zapewnienie wysokiej jakości zatrudnienia w pełnym wymiarze czasu pracy oraz opracowania i wdrożenia usług wspomagających, które odpowiadają stosownym potrzebom kobiet i mężczyzn;

— zapobieganie i zwalczanie przemocy ze względu na płeć w tym handlu ludźmi w celu wykorzystania seksualnego i wyzysku w pracy.

\section{Zakończenie}

Z poczynionej analizy wynika, że sytuacja kobiet na europejskim rynku pracy w ciagu ostatniej dekady uległa znaczącej poprawie. Służą temu m.in. rozbudowane instrumenty prawne zawarte w Traktacie o funkcjonowaniu Unii Europejskiej i tzw. ,dyrektywach równościowych". Pomimo rozbudowanego i umiarkowanie spójnego systemu ochrony prawnej kobiet na rynku pracy w dalszym ciagu zauważalna jest ich słabsza pozycja w stosunku do mężczyzn. Istotnym problemem jest segregacja pod względem płci w Unii Europejskiej wyrażająca się m.in. w ograniczaniu dostępu kobiet do atrakcyjnych stanowisk oraz luką płacową, tj. otrzymywanym przez nie zazwyczaj niższym wynagrodzeniem od mężczyzn zatrudnianych na podobnych stanowiskach. Na zmniejszenie aktywności kobiet w życiu zawodowym wpływają też inne czynniki. Przez długi czas kobiety znacząco ustępowały mężczyznom pod względem wykształcenia. Jednakże w ostatnim czasie różnice w tym względzie stopniowo ulegają zmniejszeniu. W dalszym ciagu jednakże czynnikiem pogarszającym partycypację kobiet w europejskim rynku pracy jest brak odpowiedniej liczby miejsc opieki nad dziećmi. Warto tu zauważyć, że przeciwstawianie sobie demografii i zatrudnienia wyrażające wątpliwość, czy kobieta ma wybrać pracę czy też dom i rodzinę, jest fałszywym postawieniem problemu. Fakt ten wyraźnie dostrzeżono w strategii Europa 2020, w której pomiędzy zatrudnieniem kobiet a ich tradycyjną rolą opiekunek domowego ogniska stworzone zostaje sprzężenie zwrotne. Umożliwiają to elastyczne instrumenty rynku pracy, takie jak umowy charakterystyczne dla modelu flexecurity - np. umowy niestandardowe i o elastycznych standardach. Należy mieć nadzieję, że ich zastosowanie pozwoli na utrzymanie pozytywnego trendu, którego przejawem w ostatnich latach jest wzrost stopy zatrudnia wśród kobiet.

\section{Bibliografia}

Andruszkiewicz I., Konsekwencje zjawiska bezrobocia wśród kobiet, „Przegląd Politologiczny” 2009 , nr 1. Barcz J., Kawecka-Wyrzykowska E., Michałowska-Gorywoda K., Integracja europejska, Warszawa 2007.

Bettio F., Verashchagina V., Gender segregation in the labour market, European Commission, 2009.

Bryła J., Stosunki międzynarodowe na półkuli zachodniej, w: Stosunki międzynarodowe, red. W. Malendowski, Cz. Mojsiewicz, Wrocław 2004.

Carabelli A., Parisi D., Rosselli A., Che genere di economista: una ricerca sulla professione di economista nell'università italiana, Il Mulino (Collana S.I.E.), Bologna 1999.

De Henau J., Gender role attitudes, work decisions and social policies in Europe - A series of empirical essays, doctoral thesis under the direction of Prof. D. Meulders (Université Libre de Bruxelles), 2006.

Dz. Urz. WE 1975 L 45/19.

Dz. Urz. WE L 269/15 z 2002 r. Por. wyrok ETS w sprawie Kalanke, C-450/93 z 7 października 1995, Zb. Orz. 1995.

Dz. Urz. WE 1986 L 359/56. 
Dz. Urz. WE 1996 L 145/4.

Dz. Urz. WE 1998 L 14/6.

Emmert F., Morawiecki M., Prawo europejskie, Warszawa-Wrocław 2002.

Europa łaczy sity $w$ walce z ubóstwem $i$ wykluczeniem społecznym, komunikat prasowy Parlamentu Europejskiego nr 20100212STO68925, www.europarl/europa.eu z 15.02.2010 r.

European Commission, Joint Employment Report 1997, DG V, Brussels 1997.

Gender and sustainable development. Maximising the economic, social and environmental role of women, OECD, 2008.

Gender equality In the EU In 2009-summary, Special Eurobarometer 326/Wave 72.2 - TNS Opinion and Social.

Głogosz D., Instytucje opieki nad dziećmi w krajach Unii Europejskiej. Wskazania dla Polski, „Polityka Społeczna” 2004, nr 9.

http://epp.eurostat.ec.europa.eu/tgm/table.do?tab=table\&init=1\&plugin=1\&language=en\&pcode=tsiem010, odczyt z dnia 7.02.2011 r.

http://epp.eurostat.ec.europa.eu/tgm/table.do?tab=table\&init=1\&plugin=1\&language=en \&pcode=tsiem040, odczyt z dn. 8.02.2011 r.

Karta Praw Podstawowych Unii Europejskiej (nr 2007/C 303/01) z dnia 14 grudnia 2007 r. (Dz. Urz. UE 2007 C3030).

Key figures on Europe, Eurostat pocketbooks, Komisja Europejska, 2010.

Kopaliński W., Słownik wyrazów obcych, PWN, Warszawa 1998.

Maier F. (A. H. Carl research assistance), Gender segregation in the labour market: root causes, implications and policy responses in Germany, 2008.

Ministerstwo Edukacji Narodowej i Sportu, Strategia rozwoju edukacji na lata 2007-2013, Warszawa 2005.

Muczyński M., Żylne M., Ewaluacja strategii uelastycznienia przedszkoli i żłobków, Białystok 2008.

Narodowa Strategia Integracji Społecznej dla Polski (2004), Zespół Zadaniowy ds. Reintegracji Społecznej, Warszawa 2004.

Praca i zarzqdzanie kapitatem ludzkim w perspektywie europejskiej, red. A. Pocztowski, Kraków 2005.

Report on equality between women and men 2010, European Commission, Luxembourg 2010.

Równość kobiet i mężczyzn - rok 2010, Sprawozdanie Komisji dla Rady, Parlamentu Europejskiego, Europejskiego Komitetu Ekonomiczno-Społecznego i Komitetu Regionów KOM(2009)694 wersja ostateczna, Bruksela, dnia 18.12.2009.

Smith M., Bettio M. F., Analysis Note: The economic case for gender equality, EGGE, 2008.

Sprawa 43/75 Gabrielle Defrenne v. Sabena, Zb. Orz. 1976.

Where are the women in politics? Despite huge progress in the area of gender equality, men still call the shots in the political world, „Social Agenda”, October 2008.

Zielona Księga, Modernizacja prawa pracy w celu sprostania wyzwaniom XXI wieku, Komisja Europejska KOM (2006) 708 wersja ostateczna, Bruksela, 22.11.2006.

\section{Summary}

\section{The Situation of Women in the European Labor Market}

The considerations presented in the paper demonstrate that the situation of women in the European labor market has considerably improved over the last decade. This is facilitated, among other things, by the extensive legal instruments stipulated in the Treaty on the Functioning of the European Union and in so-called 'equality directives'. Yet, despite this extensive and moderately coherent system of legal protection of women in the labor market, they continue to have a weaker position than men. Gender segregation in the European Union is a considerable problem; it is exemplified by women's limited access to attractive positions 
and a gender pay gap, i.e. obtaining lower remuneration than men employed in comparable positions. There are also other factors that influence limited women's activity in professional life. For a long time women have been second to men in terms of education, but the differences in this area have been gradually decreasing in recent times. What continues to be a factor to curb the participation of women in the European labor market is insufficient childcare provisions. It should be pointed out that confronting demography with employment, and requesting that women choose between home and family or work falsifies the problem. This has clearly been noted in the Europe 2020 strategy, which creates a feedback between women's employment and their traditional role of guardians of home and hearth. This is facilitated by flexible instruments in the labor market, such as contracts typical for a flexecurity model, e.g. non-standard contracts and flexible hour contracts. Their implementation can contribute to maintaining a positive trend that has recently been manifested in an increasing rate of employed women. 
